\title{
Cytomorphological study of mesenchymal spindle cell lesions of soft tissues by fine needle aspiration cytology
}

\author{
Kanika Rastogi ${ }^{1}$, Deepa Rani ${ }^{2, *}$, Atul Gupta ${ }^{3}$ \\ ${ }^{1}$ Junior Resident, ${ }^{2}$ Associate Professor, ${ }^{3}$ Professor, Dept. of Pathology, S.N. Medical College, Agra, Uttar Pradesh, India
}

*Corresponding Author: Deepa Rani

Email: deepasnmc@gmail.com

Received: $31^{\text {st }}$ May, 2018

Accepted: $26^{\text {th }}$ June, 2018

\begin{abstract}
Introduction: The objective of this study was to determine the scope of fine needle aspiration cytology (FNAC) in diagnosing mesenchymal spindle cell lesions of soft tissues. Cytological findings of 52 cases were evaluated.

Materials and Methods: Conventional May- Grunwald Giemsa (MGG) staining was done in all the 52 cases. Histopathology was available in 19 cases. The cytological findings were correlated with histology in these cases.

Results: Out of 52 cases, 39 were benign whereas 13 cases were malignant. Among benign spindle cell lesions, schwannoma was the commonest, followed by nodular fasciitis. Among malignant spindle cell lesions, dermatofibrosarcoma protuberans (DFSP) was the commonest tumor. Cytological and histological correlation could be achieved in 19 cases, with an accuracy of $89.47 \%$. The overall sensitivity and specificity was $83.33 \%$ and $92.31 \%$ respectively.

Conclusion: FNAC is a simple, inexpensive and rapid method to provide a reliable diagnosis to the clinician at initial presentation in mesenchymal spindle cell lesions, especially when used in conjunction with clinical data.
\end{abstract}

Keywords: FNAC, Mesenchymal spindle cell lesion, Benign and malignant.

\section{Introduction}

Soft tissue tumors are a highly heterogeneous group of tumors that are classified by the line of differentiation, according to the adult tissue they resemble. ${ }^{1}$ The incidence of soft tissue tumors is difficult to estimate, especially the ratio of benign to malignant. Benign lesions are usually estimated to be approximately 100 times more frequent than sarcomas. ${ }^{2}$ Numerous primary tumors and pseudotumors of soft tissues contain a variable number of spindle cells. Spindle cell tumors of soft tissues are often a source of diagnostic problems for surgical pathologists. The most common issues include (1) distinguishing a nonmesenchymal malignant spindle cell neoplasm (e.g. spindle cell sarcoma) from a true sarcoma, (2) discriminating between a benign spindle cell lesion and a malignant one, and (3) classifying (i.e. typing and subtyping) and grading a spindle cell sarcoma. Some particular histologic features (myxoid stroma, prominent inflammatory infiltrate, degenerative changes) may complicate the differential diagnosis. ${ }^{3}$

This study was undertaken in view of gross underutilization of FNAC for spindle cell lesions and diagnostic difficulties posed by this group.

\section{Aims}

1. To estimate the frequency of mesenchymal spindle cell lesions in aspirates obtained from soft tissue swellings.

2. To stratify the tumors into various cytomorphological categories.

3. To identify the problems encountered in cytological interpretation of aspirates from soft tissue swellings and to compare the results with histology, if available.

\section{Materials and Methods}

The material for the study was collected from the patients being referred to the FNAC clinic, with a clinical diagnosis of soft tissue tumor. All the patients referred with soft tissue swelling, showing spindle cells in their aspirates were included in the study. Aspiration was carried out using a 22 gauge needle attached to a $20 \mathrm{ml}$ syringe. Aspirated material was then spread on the slides and smears were prepared. Air dried, methanol fixed smears were then stained with MGG. The cytological findings of the smears, the clinical findings and the radiologic findings were studied to reach the diagnosis. The cytological findings were correlated with the histology in 19 cases.

\section{Results}

FNAC was carried out on 216 cases of soft tissue swellings. Out of these, 55 cases $(25.5 \%)$ were spindle cell lesions. In our study, there were 32 males and 23 females. Male to female ratio was 1.4:1. Youngest patient in our series was of 7 years of age and the oldest one was of 80 years. Maximum number of cases were in $2^{\text {nd }}$ to $5^{\text {th }}$ decade. The adequacy was obtained in 52 cases $(94.5 \%)$.The aspirates were considered inadequate when they comprised of only few spindle cells, with or without blood. Majority of the cases in our study were found to be benign-39 cases (75\%), while only 13 cases were malignant (25\%). [Table 1]. 
Table 1: Distribution of cases (Benign/Malignant):

\begin{tabular}{|l|c|c|}
\hline Type of tumor & Number of cases & Percentage \\
\hline Benign & 39 & $75 \%$ \\
\hline Malignant & 13 & $25 \%$ \\
\hline Total & 52 & $100 \%$ \\
\hline
\end{tabular}

In our study, upper limb was found to be the most common site for spindle cell lesions of soft tissues-13 cases $(25 \%)$, followed by head and neck-12 cases $(23.1 \%)$ and abdomen-11 cases $(21.2 \%)$.Next common sites were lower limb-10 cases (19.2\%), thorax-5 cases $(9.6 \%)$ and back-1 case $(1.9 \%)$. [Table 2].

Table 2: Site wise distribution of spindle cell lesions of soft tissue

\begin{tabular}{|l|c|c|c|c|}
\hline \multicolumn{1}{|c|}{ Site of lesion } & Benign & Malignant & Total & Percentage \\
\hline Head and neck & 09 & 03 & 12 & $23.1 \%$ \\
\hline Upper limb & 12 & 01 & 13 & $25 \%$ \\
\hline Thorax & 04 & 01 & 05 & $9.6 \%$ \\
\hline Abdomen & 07 & 04 & 11 & $21.2 \%$ \\
\hline Back & 01 & 00 & 01 & $1.9 \%$ \\
\hline Lower limb & 06 & 04 & 10 & 19.2 \\
\hline Total & 39 & 13 & 52 & $100 \%$ \\
\hline
\end{tabular}

In our study, out of thirty nine cytologically diagnosed benign spindle cell lesions, schwannoma was found to be the most common tumor-12 cases(30.8\%), followed by nodular fasciitis-06 cases (15.5\%) and four cases $(10.2 \%)$ each of proliferative fasciitis and fibromatosis.[Fig. 1-3]. Two cases(5.1\%) each of spindle cell lipoma, hemangioma, tenosynovial giant cell tumor and cutaneous leiomyoma were reported. One case $(2.6 \%)$ each of pleomorphic lipoma, endometriosis, inflammatory lesion, superficial angiomyxoma and neurofibroma was also diagnosed [Fig. 4].

Of the thirteen cytologically diagnosed malignant spindle cell lesions, DFSP was found to be the most common-3 cases (23.2\%),followed by two cases $(15.4 \%)$ each of extra-gastrointestinal stromal tumor, synovial sarcoma, malignant mesenchymal spindle cell lesion and undifferentiated pleomorphic sarcoma. One case $(7.6 \%)$ each of malignant peripheral nerve sheath tumor and sarcomatoid carcinoma was diagnosed [Fig. 5-6].

Histology was available in thirteen out of thirty nine cases of cytologically diagnosed benign spindle cell lesions. Histological diagnosis in eleven cases correlated with the cytological diagnosis. One case of leiomyoma turned out to be angiomyoma on histology, but since latter is a form of leiomyoma and is benign in nature, it was not considered as discordance. One discordant case was identified wherein FNAC gave false negative results. It was a low grade myofibroblastic sarcoma for which FNA diagnosis was given as proliferative fasciitis. Cytohistological correlation was found to be $92 \%$. [Table 3].

Of the thirteen malignant cases, histology was available in six cases. Histological diagnosis in five cases correlated with the cytological diagnosis. One case reported as malignant mesenchymal spindle cell lesion was found to be ancient schwannoma on histology. Cytohistological correlation was found to be 83.3\%. [Table 4].

Table 3: Correlation of cytologically diagnosed benign spindle cell lesions with histology

\begin{tabular}{|l|c|c|c|}
\hline \multicolumn{1}{|c|}{ Cases } & Histology available & Positive correlation & Misdiagnosed cases \\
\hline Schwannoma & $5 / 12$ & 05 & - \\
\hline Nodular fasciitis & $2 / 6$ & 02 & - \\
\hline Proliferative fasciitis & $1 / 4$ & - & - \\
\hline Fibromatosis & $2 / 4$ & 02 & - \\
\hline Hemangioma & $1 / 2$ & 01 & - \\
\hline Cutaneous leiomyoma & $1 / 2$ & 01 & - \\
\hline Tenosynovial giant cell tumor & $0 / 2$ & - & - \\
\hline Spindle cell lipoma & $0 / 2$ & - & - \\
\hline Pleomorphic lipoma & $0 / 1$ & - & - \\
\hline Superficial angiomyxoma & $1 / 1$ & 01 & - \\
\hline Endometriosis & $0 / 1$ & - & - \\
\hline Inflammatory lesion & $0 / 1$ & - & $1 / 13$ \\
\hline Neurofibroma & $0 / 1$ & - & \\
\hline Total & $13 / 39$ & $12 / 13$ & \\
\hline
\end{tabular}


Table 4: Correlation of cytologically diagnosed malignant spindle cell lesions with histology:

\begin{tabular}{|l|c|c|c|}
\hline \multicolumn{1}{|c|}{ Cases } & Histology available & Positive correlation & Misdiagnosed cases \\
\hline Dermatofibrosarcoma protuberans & $2 / 3$ & 2 & - \\
\hline Extra gastrointestinal stromal tumor & $0 / 2$ & - & - \\
\hline Synovial sarcoma & $1 / 2$ & 1 & - \\
\hline $\begin{array}{l}\text { Malignant mesenchymal spindle cell } \\
\text { lesion }\end{array}$ & $1 / 2$ & - & - \\
\hline $\begin{array}{l}\text { Undifferentiated pleomorphic } \\
\text { sarcoma }\end{array}$ & $0 / 2$ & - & - \\
\hline $\begin{array}{l}\text { Malignant peripheral nerve sheath } \\
\text { tumor }\end{array}$ & $1 / 1$ & 1 & - \\
\hline Sarcomatoid carcinoma & $1 / 1$ & 1 & $1 / 6$ \\
\hline Total & $6 / 13$ & $5 / 6$ & \\
\hline
\end{tabular}
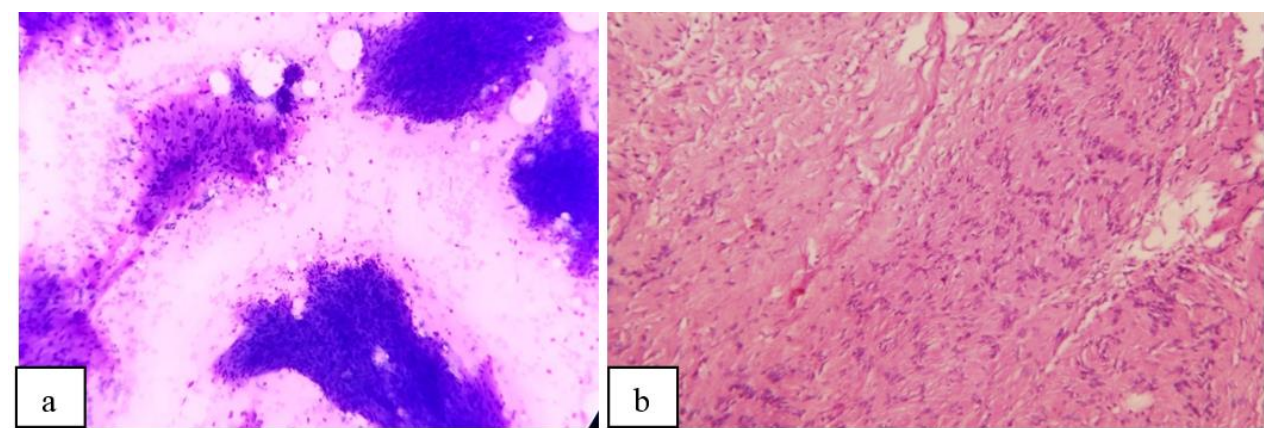

Fig. 1: (a) Schwannoma (FNAC). Almost acellular background with ellular tissue fragments of varying cellularity with irregular borders and fibrillary matrix (MGG,100x); (b): Schwannoma (HPE). Antoni A areas in schwannoma illustrating nuclear palisading with Verocay bodies. (H\&E, 100x)

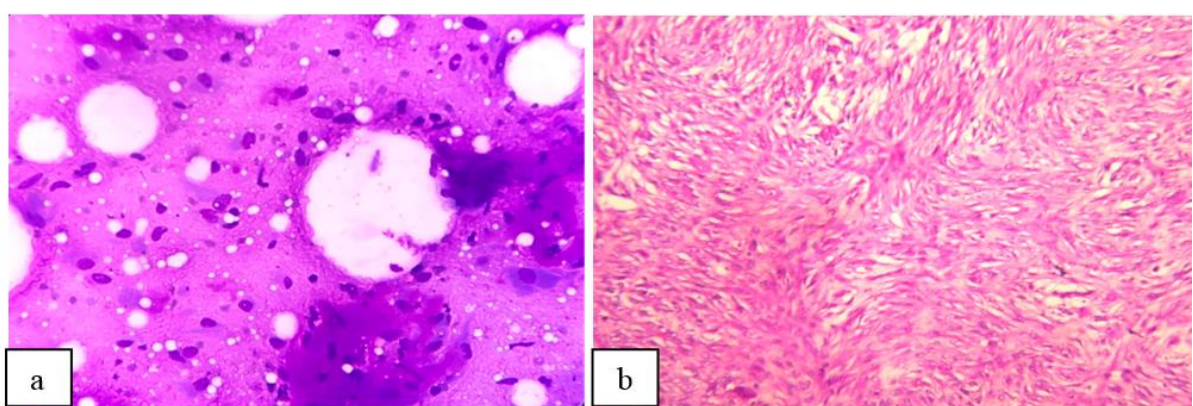

Fig. 2:(a) Nodular fasciitis (FNAC). A myxoid background matrix with dispersed arrangement of fibroblasts with storiform growth pattern. (H\&E, 400x); (b): Nodular fasciitis (HPE). Small areas of myxoid background imparting a loosely textured arrangement of fibroblasts with storiform growth pattern. $(\mathrm{H \& E}, 100 \mathrm{x})$.

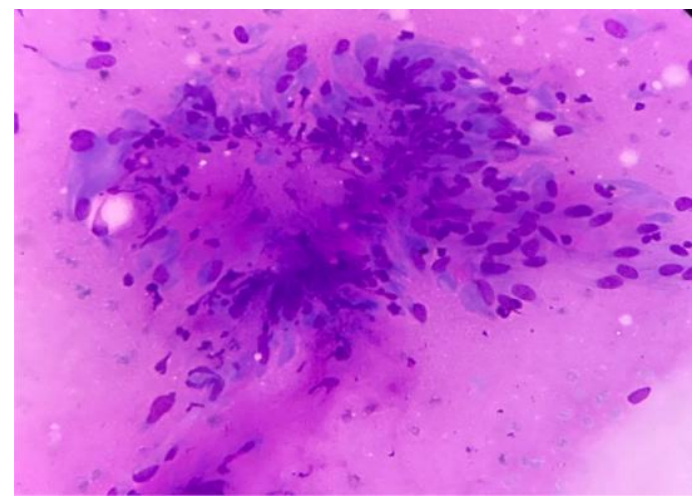

Fig. 3: Fibromatosis (FNAC). A cluster of loosely attached fibroblast-like cells with ovoid nuclei and greyishblue cytoplasm from an unusually cellular area in fibromatosis. (MGG,100x). 


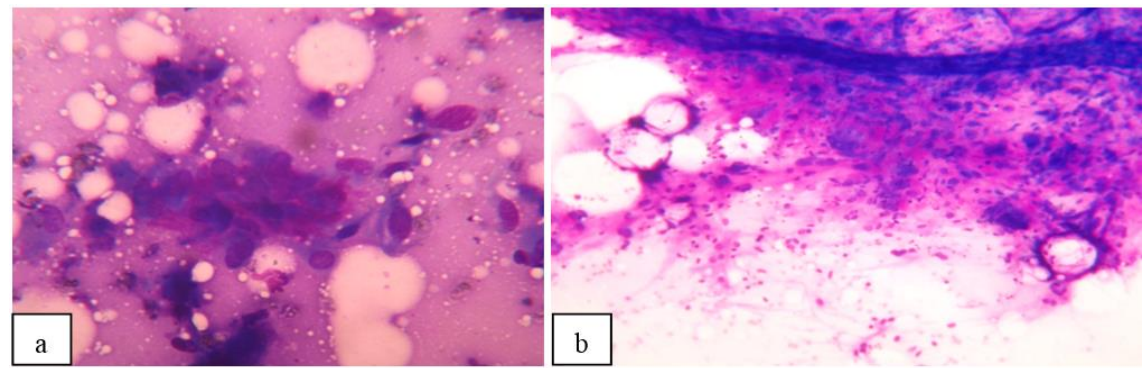

Fig. 4:(a)Cutaneous leiomyoma (FNAC). A cluster of spindle cells with blunt ended, elongated and ovoid nuclei and abundant blue grey cytoplasm in a blue red background matrix. (MGG,400x); (b): Pleomorphic lipoma (FNAC). Admixture of adipocytes and spindle cells is seen. A blood vessel is seen running in the cluster of spindle cells with fair number of floret-like giant cells. (MGG,100x).
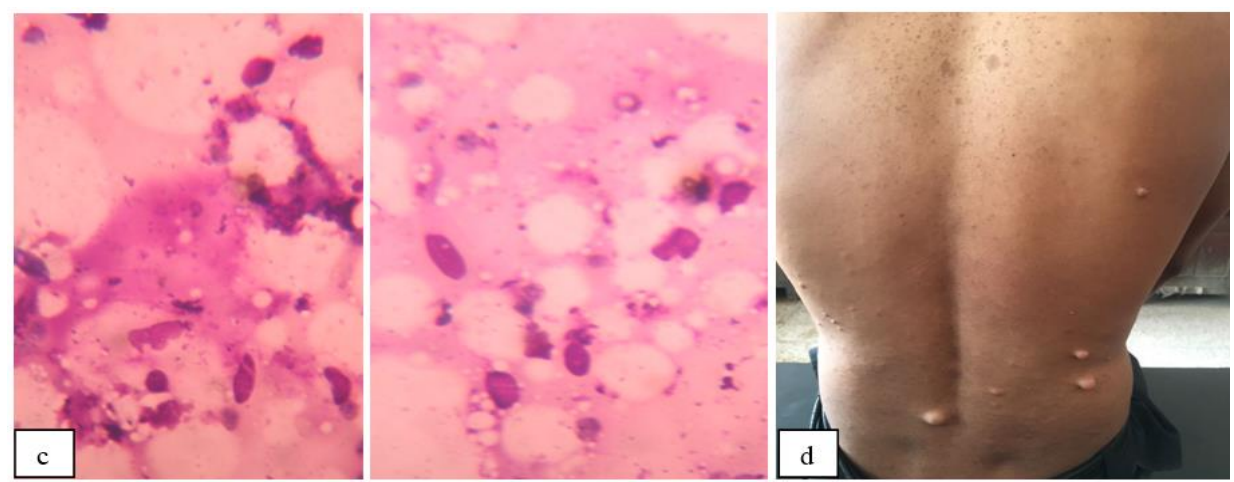

Fig. 4:(c)Neurofibroma (FNAC). Scantily cellular smears with spindle to ovoid dispersed cells in a patient of neurofibromatosis-1. (MGG,400x); (d): Patient with neurofibromatosis 1 having multiple neurofibromas
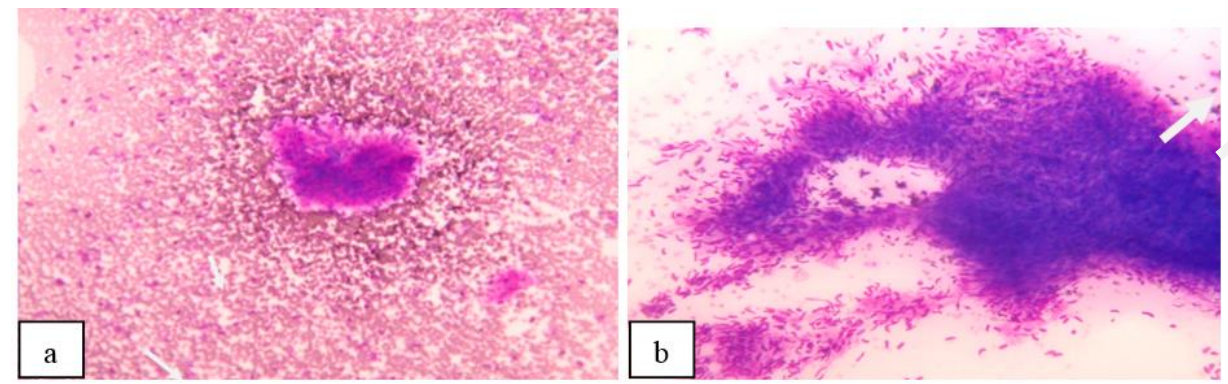

Fig. 5:(a) Dermatofibrosarcoma protuberans (FNAC). A cellular tumor fragment of cohesive spindle cells embedded in collagenous matrix. Fairly abundant dispersed cells are also seen. (MGG,100x); (b): Extragastrointestinal stromal tumor (FNAC). Tissue fragment containing spindle cells in a fibrillary background. Few dispersed cells are also seen. (MGG,100x)
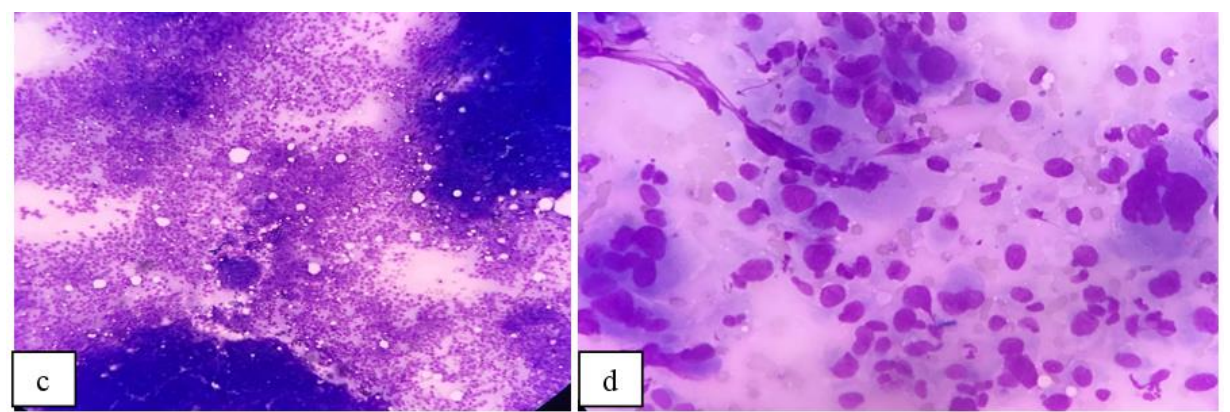

Fig. 5:(c) Synovial sarcoma (FNAC). The smear is composed of a mixture of fragments of tightly packed cells and dispersed cells. (MGG,100x); (d): Undifferentiated pleomorphic sarcoma (FNAC). Smear showing dispersed population of highly pleomorphic cells and a multinucleated giant cell. (MGG,400x). 


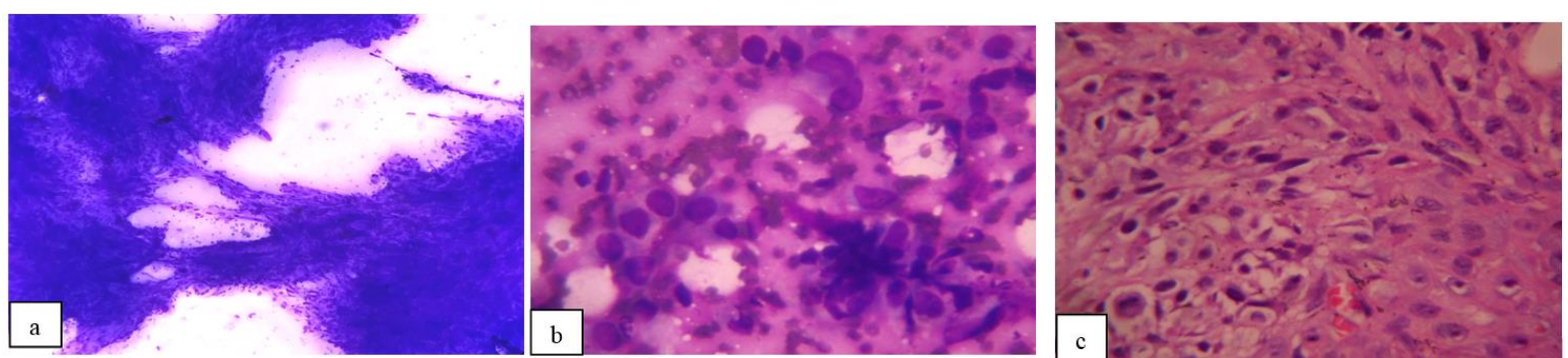

Fig. 6: (a) Malignant peripheral nerve sheath tumor (FNAC). Smear showing hypercellular clusters of spindle cells. (MGG,100x); (b): Sarcomatoid carcinoma (FNAC). Smear showing a malignant epithelial component (polygonal cells with scant basophilic cytoplasm and rounded nuclei having granular chromatin) and a spindle cell component. (MGG,400x); (c): Sarcomatoid carcinoma (HPE). Section showing malignant epithelial and spindle cell component. (H\&E,400x).

\section{Problems Encountered in Cytological Interpretation} of Spindle cell Lesions:

1. Precise diagnostic categorization (apart from benignancy/malignancy) and determination of lineage posed significant problems in some of the cases.

2. One case of pleomorphic lipoma raised suspicion of liposarcoma on FNAC. But in this case, clinical features provided clues to reach to correct diagnosis.

3. Ancient schwannoma was signed out as sarcoma on FNAC because of the presence of atypical hyperchromatic nuclei.

\section{Statistical Analysis}

True positive and true negative cases in our study were 5 and 12 respectively. While one false positive and one false negative case was reported. So accuracy was $89.47 \%$. Sensitivity and specificity were $83.33 \%$ and $92.31 \%$ respectively.

\section{Discussion}

In the present study $25.5 \%$ of all soft tissue tumors were found to have spindle cell pattern. On excluding lipomas, spindle cell lesions in our study constituted $50 \%$ of soft tissue swellings which was similar to the previous studies by other workers. In the study by Maitra A et al and Rekhi B et al, spindle cell lesions constituted $62 \%$ and $47.2 \%$ of their cases respectively. ${ }^{4,5}$ The adequacy rate in our study was 94.5\%.Our findings were similar to those of Roy S et al, who reported an adequacy rate of $93.4 \% .{ }^{6}$ Possible reasons for inadequate aspiration given by them were excessive fibrosis or necrotic/cystic change in the tumor.

In the present study, males outnumbered females by a ratio of 1.4:1, which was comparable to that reported by Tailor $\mathrm{HJ}$ et al, 1.3:1. ${ }^{7}$ There was slight variation in $\mathrm{M}: \mathrm{F}$ ratio, with a ratio of $1: 1$, reported by Hirachand $\mathrm{S}$ et al. [8]. While a ratio of $1.8: 1$ was reported by Rekhi B et al. ${ }^{5}$ Maximum number of cases in our study occurred in $2^{\text {nd }}$ to $6^{\text {th }}$ decade. Since none of the other studies focused exclusively on spindle cell lesions, our results could not be strictly compared with them. However in the study by Tailor $\mathrm{HJ}$ et $\mathrm{al}^{7}$ maximum number of cases were in 21-50 years of age group, which were somewhat similar to our findings. Upper limb (25\%) was found to be the most common site for spindle cell lesions of soft tissues in our study, followed by head and neck $(23.1 \%)$ and abdomen $(21.2 \%)$.This was similar to the findings of Tailor $\mathrm{HJ}$ et $\mathrm{al},{ }^{7}$ who also reported upper limb as the most common site for soft tissue tumors. Zubaida $\mathrm{R}$ et $\mathrm{al}^{9}$ had majority of their cases in head and neck. In the series by Kotwal $\mathrm{S}$ et $\mathrm{al},{ }^{10}$ lower limb was found to be the commonest site.

In our study, $75 \%$ cases were found to be benign, while malignant comprised only $25 \%$. These figures were somewhat comparable to studies by Tailor HJ et $\mathrm{al}^{7}$ and Kotwal $\mathrm{S}$ et al, ${ }^{10}$ who found benign tumors to be $93.5 \%$ and $82.3 \%$ respectively. However, our findings were in contrast to those reported by Rekhi B et al, in which $79.5 \%$ cases were labeled as malignant. The reason for this was the predominance of referral cases and sarcomas received in their centre. ${ }^{5}$

Out of thirty nine cytologically diagnosed benign spindle cell lesions in our study, schwannoma was found to be the most common tumor $(30.8 \%)$, followed by nodular fasciitis (15.5\%), proliferative fasciitis $(10.2 \%)$ and fibromatosis $(10.2 \%)$.Our findings were similar to those of Zubaida $\mathrm{R}$ et al who reported schwannoma as the commonest benign lesion. ${ }^{9}$ However Kotwal S et al ${ }^{10}$ and Sharath Kumar HK et al reported fibrous histiocytma to be the most common spindle cell tumor. ${ }^{10,11}$

Out of thirteen cytologically diagnosed malignant spindle cell lesions in our study, DFSP was found to be the most common (23.2\%), followed by extragastrointestinal stromal tumor, synovial sarcoma, malignant mesenchymal spindle cell lesion and undifferentiated pleomorphic sarcoma, which constituted $15.4 \%$ each. Our findings were similar to the study done by Soni PB et al, who also reported DFSP as the commonest malignant lesion. ${ }^{12}$ In the series by Sharath Kumar HK et al, malignant fibrous histiocytoma was the most common malignant tumor. ${ }^{11}$ 


\section{Cytohistological Correlation}

Cytohistological correlation for benign cases, in our study was $92 \%$.It was found to be $93 \%$ in the study by Maitra $\mathrm{A}$ et al and $90.6 \%$ by Roy $\mathrm{S}$ et al. ${ }^{4,6}$ Hence the findings were similar. For malignant cases, cytohistological correlation was $83.3 \%$ in our study. This was somewhat lower when compared to the previous studies. Maitra A et al found 94\% cytohistological correlation in malignant cases and Roy $\mathrm{S}$ et al found it to be $91.3 \%$. $^{4,6}$

Accuracy of FNAC in diagnosing spindle cell lesions of soft tissues in our study was found to be $89.47 \%$, which was comparable to the studies of Parajuli $S$ et al, who reported accuracy of $86 \%$ but lower than that reported by Arul $\mathrm{P}$ et al $(97 \%) .^{13,14}$ Sensitivity and specificity of FNAC in diagnosing spindle cell lesions were $83.3 \%$ and $92.3 \%$ respectively in our study. The figures were somewhat lower than the findings of Arul $\mathrm{P}$ et al, who reported sensitivity and specificity of $91.7 \%$ and $97.7 \% .{ }^{14}$ In our study, positive predictive value and negative predictive value were $83.3 \%$ and $92.3 \%$ respectively. The findings were comparable to those reported by Arul P et al. ${ }^{14}$

\section{Problem Areas}

A case of pleomorphic lipoma showed mature fibroadipose fragments with 'floret like giant cells'. This aroused suspicion of liposarcoma but clinical history i.e. superficial location (upper back) of the tumor in elderly male, helped in making correct diagnosis. Similar case was reported by Rekhi B et al. ${ }^{5}$ A case of ancient schwannoma was diagnosed as sarcoma on FNAC. This daunting tumor is a recognized pitfall in soft tissue tumor diagnosis. ${ }^{15,16}$ Hypercellularity of the smears and presence of large bizarre cells with irregular nuclei were causes for misinterpretation. ${ }^{16}$

\section{Conclusion}

FNAC is an excellent diagnostic technique for spindle cell lesions of soft tissues with high accuracy, sensitivity and specificity. Even though spindle cell lesions pose great diagnostic challenges in identification of specific entity, but distinction of malignant from benign lesions is usually possible.

Financial Support and Sponsorship: Nil.

Conflicts of Interest: There are no conflicts of interest.

\section{References}

1. Goldblum JR, Folpe AL, Weiss SW. Enzinger and Weiss's Soft tissue tumors. 6th ed. Philadelphia: Elsevier; 2014. Chapter 1, General considerations; p. 1-10.

2. Akerman M, Domanski HA. Soft tissue tumors - basic information. In: The cytology of soft tissue tumors. Monogr Clin Cytol. Vol.16. Basel: S Karger; 2003. p.1.

3. Enriqez AM, Guilou L, Hornick JL. Spindle cell tumors of adults. In: Hornick JL ed. Practical soft tissue
pathology-A diagnostic

approach.Philadelphia:Elsevier;2013:p.13-93.

4. Maitra A, Ashfaq R, Saboorian MH, Lindberg G,

Gokaslan ST. The role of fine needle aspiration biopsy in the primary diagnosis of mesenchymal lesions. Cancer Cytopathology. 2000;90:178-185.

5. Rekhi B, Gorad BD, Kakade AC, Chinoy RF. Scope of FNAC in the diagnosis of soft tissue tumors-A study in a tertiary cancer referral centre in India. Cytojournal. 2007;4:20.

6. Roy S, Manna AK, Pathak S, Guha D.Evaluation of fine needle aspiration cytology and its correlation with histopathological findings in soft tissue tumours. J Cytol. 2007;24:37-40.

7. Tailor HJ, Bhagat VM, Kaptan KBR, Italiya SL, Balar HR, Agarwal MP. Diagnostic accuracy of fine needle aspiration cytology in soft tissue tumours: Our institutional experience. Int J Res Med Sci. 2013;1:443447.

8. Hirachand S, Lakhey M, Singha AK, Devkota S, Akhter J. Fine needle aspiration of soft tissue tumours. Kathmandu Univ Medical J. 2007;5:374-377.

9. Rasool Z, Bhat ML, Samoon N, Baba K, Rumana M, Reshi $R$ et al. Utility of fine needle aspiration cytology in diagnosis of soft tissue lesions with histopathological correlation. GJMEDPH. 2013;2:1-7.

10. Kotwal S, Gupta D, Suri J. Role of fine needle aspiration cytology in diagnosis of soft tissue tumors; benefits and limitations: A two year retrospective study. J Evid based Med Healthcare. 2016;3:1019-1024.

11. Sharath Kumar HK, Gayathri MN, Shailaja MD. Cytopathology of soft tissue tumours with their varying presentations. JMSCR. 2017;5:15350-15354.

12. Soni PB, Verma AK, Chandoke RK, Nigam JS.A prospective study of soft tissue tumours:

Histocytopathology correlation. Pathology Research International 2014; Article ID 678628.

13. Parajuli S, Lakhey M. Efficacy of fine needle aspiration cytology in diagnosing soft tissue tumors. Journal of Pathol of Nepal. 2012;2:305-308.

14. Arul P, Masilamani S. Fine needle aspiration cytology of soft tissue tumors with its histopathological correlation in a rural hospital of South India: A retrospective study. Clin Cancer Investig J. 2016;5:146-150.

15. Kulkarni DR, Kokandakar HR, Kumbhakarna NR, Bhople KS. Fine needle aspiration cytology of soft tissue tumors in correlation with histopathology. Indian $J$ Pathol Microbiol. 2002;45:45-48.

16. Basu N, Biswas P, Mallick MG, Mondal SK, Sengupta S. Role of cytology in diagnosis of soft tissue sarcomas with special reference to false positive cases. Journal of Cytology. 2009;26:15-19.

How to cite this article: Rastogi $\mathrm{K}$, Rani D, Gupta A. Cytomorphological study of mesenchymal spindle cell lesions of soft tissues by fine needle aspiration cytology. Indian $\mathbf{J}$ Pathol Oncol. 2018;5(4):542-547. 